\title{
Some Thoughts on the Freezing and Melting of Sea Ice and Their Effects on the Ocean
}

\author{
K. Aagaard and R. A. Woodgate \\ Polar Science Center, Applied Physics Laboratory \\ University of Washington \\ 1013 N.E. $40^{\text {th }}$ Street \\ Seattle, WA $98105-6698$ \\ U.S.A \\ aagaard@apl.washington.edu
}

January 2001

This publication is partially funded by the Joint Institute for the Study of the Atmosphere and the Ocean (JISAO) under NOAA Cooperative Agreement No. NA67RJ0155, Contribution No. 679. The views expressed herein are those of the authors and do not necessarily reflect the views of NOAA or any of its subagencies. 
Abstract. The high-latitude freezing and melting cycle can variously result in haline convection, freshwater capping, or freshwater injection into the interior ocean. An example of the latter process is a secondary salinity minimum near $800 \mathrm{~m}$ depth within the Arctic Ocean that results from the transformation on the Barents Sea shelf of Atlantic water from the Norwegian Sea and its subsequent intrusion into the Arctic Ocean. About onethird of the freshening on the shelf of that initially saline water appears to result from ice melt, although the actual sea ice flux is small, only about $0.005 \mathrm{~Sv}$. A curious feature of this process is that water distilled at the surface of the Arctic Ocean by freezing ends up at mid-depth in the same ocean. This is a consequence of the ice being exported southward onto the shelf, melted, and then entrained into the northerly Barents Sea throughflow that subsequently sinks into the Arctic Ocean. Prolonged reduction in sea ice in the region and in the concomitant freshwater injection would likely result in a warmer and more saline interior Arctic Ocean below $800 \mathrm{~m}$. 


\title{
Some Thoughts on the Freezing and Melting of Sea Ice and Their Effects on the Ocean
}

\author{
K. Aagaard and R. A. Woodgate
}

\section{Introduction}

Evaporation and precipitation rates over the Arctic Ocean are quite low, respectively about $5-10 \mathrm{~cm} \mathrm{yr}^{-1}$ and $20-30 \mathrm{~cm} \mathrm{yr}^{-1}$ in liquid water equivalent (Barry and Serreze, 2000). The primary cycling of freshwater in the Arctic Ocean is therefore instead accomplished by the freezing and melting of sea ice, for which characteristic rates are about $100 \mathrm{~cm} \mathrm{yr}^{-1}$ and $50 \mathrm{~cm} \mathrm{yr}^{-1}$, respectively (Steele and Flato, 2000). If the ice drifts during the long intervals between the phase changes, the result is a net local distillation, since the freezing process expels the majority of the salt in the freezing water into the underlying ocean. This freezing and melting of sea ice, with their accompanying salinity changes, provide buoyancy forcing that is particularly effective in influencing the circulation because of the primary control of density by salinity at the prevailing low temperatures. For example, Holland, Mysak and Oberhuber (1996) concluded that buoyancy forcing is critical to maintaining the mixed layer circulation in the Arctic Ocean. The present note points to the range of buoyancy forcing that is possible in the high-latitude ocean. We begin with an example from the northern North Atlantic extension, viz., the cooling and freshening of the Atlantic water on the Barents shelf. We then place this process in the broader context of interactions between sea ice and the ocean. The intent is to thereby call attention to some appropriate, and even necessary, considerations in modelling the high-latitude ocean, especially in regard to the possible restructuring of ocean properties under altered climatic conditions.

\section{An example: transformation of the Barents Sea throughflow}

Consider initially the final northward push of the meridional oceanic transport in the North Atlantic system, from the Norwegian Sea into the Arctic Ocean, which occurs in two branches. One branch follows the deep water route west of Spitsbergen through Fram Strait, while the other crosses the great shelf of the Barents Sea, entering the Polar Basin from the northern Kara Sea (Rudels, Jones, Anderson and Kattner 1994; Schauer, Muench, Rudels and Timokhov, 1997). The former route results in a layer within the Arctic Ocean that exhibits the Atlantic influence in its purest form, warm and saline. The Barents Sea route yields a cooler and fresher Atlantic presence in the Arctic Ocean (Schauer, Muench, Rudels and Timokhov, 1997). The products within the Arctic Ocean of these two circulation branches have in recent years been respectively referred to as the Fram Strait (FSBW) and Barents Sea branch waters (BSBW).

The transformation of the Atlantic water from the Norwegian Sea to BSBW involves a substantial cooling, on the average more than $4^{\circ} \mathrm{C}$, but also a modest freshening, about 0.2 in salinity (all salinities are given as PSU), so that the net result is only a small increase in density of about $0.2 \mathrm{~kg} \mathrm{~m}^{-3}$. Were the Norwegian Sea water not freshened during the shelf transit, but only cooled, the throughflow in the Barents Sea would be adding very dense water to the Polar Basin, near $1028.2 \mathrm{~kg} \mathrm{~m}^{-3}$ referenced to surface pressure. Water that dense would lie near the bottom of the deep basin, rather than near $800 \mathrm{~m}$, which is presently the case. Important questions are therefore what causes the freshening, without which the BSBW would be extremely dense, and what changes in the 
transformation on the shelf might be possible under altered surface forcing.

In principle, ice melt, runoff, and precipitation could all be responsible for the freshening, but we can distinguish between the effects of ice melt and meteoric water by using oxygen isotope information (Östlund and Hut, 1984). In the arguments that follow we will not distinguish between runoff and precipitation, although other tracers may provide that capability (Guay and Falkner, 1997; Olsson and Anderson, 1997).

The annual mean initial temperature and salinity of the Atlantic water coming onto the Barents shelf might reasonably be taken as $4.5^{\circ} \mathrm{C}$ and 35.1 , respectively. This agrees with the summer observations by Blindheim and Loeng (1981), with the temperature corrected for the annual cycle (Mosby, 1970). The $\Delta^{18} \mathrm{O}$ value for the Atlantic water is about 0.3 (Ekwurzel, 1998; Ekwurzel, Schlosser, Swift, Mortlock and Fairbanks, submitted; Mensch, Frank, Stein and Bayer, submitted).

Profiles of the nuclear fuel reprocessing tracers ${ }^{129}$ and ${ }^{237} \mathrm{~Np}$ from over the base of the Laptev Sea slope both show a distinct secondary maximum near $800 \mathrm{~m}$ depth, evidence of recent intrusions from the shelf (Cooper, Beasley, Aagaard, Kelley, Larsen and Grebmeier, 1999). These maxima coincide with the BSBW core described by Schauer, Muench, Rudels and Timokhov (1997), and indeed the radionuclide data are from the same cruise as theirs. Especially important is the coincidence of the radionuclide tracer maxima with a relative minimum in salinity of 34.86 . The corresponding temperature is $0^{\circ} \mathrm{C}$. As a first approximation we take this water near $800 \mathrm{~m}$ to represent the fully transformed BSBW. The $\Delta^{18} \mathrm{O}$ value for this water is very near 0.25 (Frank, 1996).

We also need $\Delta^{18} \mathrm{O}$ values for the sea ice and runoff (the latter assumed to be combined with precipitation), together with the bulk salinity of the ice. For the ice, 4 is a reasonable value of salinity, noting that the calculations that follow are rather insensitive to realistic variations in that choice (cf., Figure 1 and accompanying discussion). The $\Delta^{18} \mathrm{O}$ for the ice can be estimated from the value in surface waters in the southwestern Eurasian Basin (Frank, 1996), corrected by the fractionation effect on freezing (Macdonald, Paton and Carmack, 1995), giving about +1 . An appropriate number for $\Delta^{18} \mathrm{O}$ for runoff is less certain. Runoff into the Barents and Kara seas characteristically has $\Delta^{18} \mathrm{O}$ near -14 and -17, respectively (Ekwurzel, 1998; Ekwurzel, Schlosser, Swift, Mortlock and Fairbanks, submitted). Runoff entering the region via the Norwegian Coastal Current, which undoubtedly is supplying much of the nuclear fuel reprocessing material observed over the Laptev Sea continental slope (Kershaw and Baxter, 1995), is considerably less deficient in ${ }^{18} \mathrm{O}$, perhaps -10 being a representative value for $\Delta^{18} \mathrm{O}$ (Mensch, Frank, Stein and Bayer, submitted). Isotopic measurements of precipitation near the Barents coast at $69^{\circ} \mathrm{N}, 33^{\circ} \mathrm{E}$ are typically in the range -10 to -17 , with a long-term mean near-13 (IAEA/WMO, 1999). Assuming a mixture of these source characteristics suggests that a reasonable value of $\Delta^{18} \mathrm{O}$ for runoff in the Barents Sea might be in the range -10 to -14 . We take the value -11 , which emphasizes the likely dominant contribution from the Norwegian Coastal Current and will result in a conservatively low estimate of ice melt (cf., Figure 1).

The conservation equations for total mass, salinity, and $\Delta^{18} \mathrm{O}$ as given by Östlund and Hut (1984) are

$$
a+r+i=1
$$




$$
\begin{aligned}
& \mathrm{S}_{\mathrm{a}} \mathrm{a}+\mathrm{S}_{\mathrm{i}} \mathrm{i}=\mathrm{S}_{\mathrm{b}} \text {, and } \\
& \Delta^{18} \mathrm{O}_{\mathrm{a}} \mathrm{a}+\Delta^{18} \mathrm{O}_{\mathrm{r}} \mathrm{r}+\Delta^{18} \mathrm{O}_{\mathrm{i}} \mathrm{i}=\Delta^{18} \mathrm{O}_{\mathrm{b}},
\end{aligned}
$$

where $\mathrm{a}, \mathrm{r}$, and $\mathrm{i}$ are respectively the mass fraction contributions of the Atlantic water, runoff, and ice to the BSBW. The corresponding salinities, $\mathrm{S}$, and $\Delta^{18} \mathrm{O}$ values are subscripted accordingly, while the subscript $b$ denotes BSBW values.

Using the observed and estimated values cited (which are summarized in Table 1 ), we find that the ratio of the meltwater contribution to that of the combined runoff and precipitation is 0.56 , so that about $35 \%$ of the freshening of the Atlantic water as it traverses the shelf is due to ice melt. The amount of meltwater involved is not large in absolute terms, however. For example, if we take the flux of Atlantic water onto the Barents Sea shelf to be 2 Sv (Blindheim, 1989; Loeng, Ozhigin, Ådlandsvik and Sagen, 1993), the freshwater flux onto the same shelf in the form of ice is near $0.005 \mathrm{~Sv}$. (This calculation assumes that all the ice melts and is entrained into the throughflow.) We note that this on-shelf ice flux is similar to (about one-half) that estimated by Woodgate, Aagaard, Muench, Gunn, Björk, Rudels, Roach and Schauer (in press) for the Barents Sea in 1993-94. We note also that the 0.005 Sv on-shelf ice flux is only about $5 \%$ of the estimated ice transport southward through Fram Strait (Vinje, Nordlund and Kvambekk, 1998), and so the flux of ice onto the Barents shelf does not greatly affect estimates of total ice export from the Arctic Ocean.

Table 1. Water type characteristics

$\begin{array}{lccc}\text { Water type } & \text { Temperature } & \text { Salinity } & \Delta^{18} \mathrm{O} \\ \text { Atlantic } & 4.5^{\circ} \mathrm{C} & 35.1 & +0.3 \\ \begin{array}{l}\text { Runoff } \\ \text { (including } \\ \text { precipitation) }\end{array} & & 0 & -11 \\ \text { Sea ice } & & & \\ \text { BSBW } & 0^{\circ} \mathrm{C} & 34.86 & +1\end{array}$

The heat flux needed to melt the ice is also small, only $1.6 \times 10^{12} \mathrm{~W}$, whereas the temperature decrease in the Atlantic water transformation represents a much larger heat loss of $38 \times 10^{12} \mathrm{~W}$. Therefore, on average, only about $4 \%$ of the oceanic heat loss represented by the transformation of Atlantic water on the shelf is used to melt ice. The remaining heat is primarily lost to the atmosphere (cf., Steele and Morison, 1993).

The time required for the overall transformation can be estimated from the advective time scale. The distance from the Barents Sea shelf break in the west to St. Anna Canyon in the central Kara Sea, where the BSBW is believed to enter the Arctic Ocean (Schauer, Muench, Rudels and Timokhov, 1997), is about $2000 \mathrm{~km}$. For a typical advection of $4 \mathrm{~cm} \mathrm{~s}^{-1}$ (Loeng, Ozhigin, Ådlandsvik and Sagen, 1993) this gives a translation time of about 19 months for the throughflow, i.e., about one-half the mean residence time of runoff on these shelves (Schlosser, Grabitz, Fairbanks and Bönisch, 1994). A parcel 
of water from the Norwegian Sea transiting the shelf will therefore be exposed to at least one full annual cycle of cooling and freshening during its transformation.

The uncertainties in these various calculations are undoubtedly large. As an extreme example, if we consider the entire possible range of $\Delta^{18} \mathrm{O}$ in the Atlantic water before it enters the Barents Sea, viz., +0.25 to +0.35 (Ekwurzel, 1998), the corresponding fractions of ice melt are respectively $94 \%$ and $0 \%$. The value for $\Delta^{18} \mathrm{O}_{a}$ of 0.32 proposed by Mensch, Frank, Stein and Bayer (submitted) yields a meltwater fraction of only $10 \%$. On the other hand, if the final salinity of the BSBW is assumed to be 34.88 instead of 34.86 , but other values are as in Table 1, about $30 \%$ of the freshening is still indicated to be by meltwater. These and other parameter ranges are explored systematically in Figure 1, showing the fraction of the freshening of the Atlantic water due to ice melt under various assumptions. Note that the calculation is rather insensitive to the choices of $\Delta^{18} \mathrm{O}$ and salinity for the ice, as well as to the salinity of the final mixture representing BSBW. 

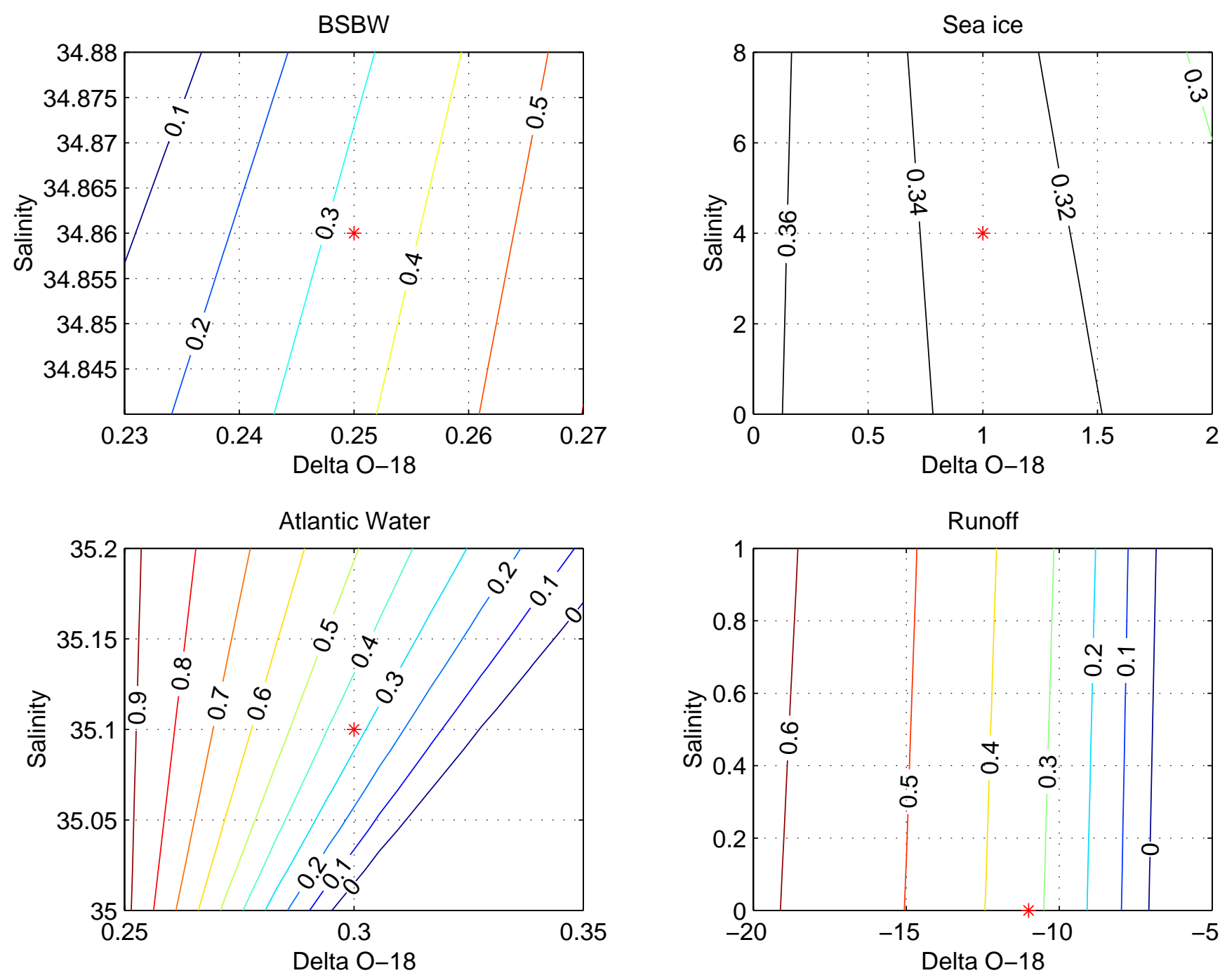

Figure 1. Contours of the fractional freshening of the Atlantic water on the Barents shelf due to ice melt, for a range of salinity (ordinate) and D180 (abscissa) associated with the various mixing components. The stars represent the freshening corresponding to the parameter choices of Table 1. 
Independent evidence for the importance of ice melt in modifying the characteristics of the Atlantic layer within the Arctic Ocean has been offered by Woodgate, Aagaard, Muench, Gunn, Björk, Rudels, Roach and Schauer (in press). They found a cooling and freshening of the Atlantic layer over the Eurasian continental slope in the mid-1990s that was consistent with an increased inflow of ice from the Arctic Ocean to the Barents Sea, the extra melting of which modified the source waters over the shelf.

We therefore conclude that the relatively low salinity of the BSBW within the Arctic Ocean results at least in part from an admixture of ice melt in the Barents Sea, with a likely proportion of about one-third of the total freshening being due to ice melt.

\section{Discussion}

The freezing of seawater in the high-latitude ocean represents an important distillation analagous to evaporation at lower latitudes, and the fate of the products of that freezing, and of the subsequent melting (analagous to precipitation), can be considered to fall into one of three categories (Figure 2). In the first of these, the dense distillation residue (the brine) is injected into the ocean, driving gravitational convection. That injection is believed to be an important contributor to the properties of shelf waters in both the Antarctic (Gill, 1973) and the Arctic (Aagaard, Coachman and Carmack, 1981). These brine-enriched shelf waters in turn contribute to larger-scale circulations, e.g., the deep ventilation of the Southern Ocean (Foldvik, Gammelsrød and Tørresen, 1985) and the shallower ventilation of the Arctic Ocean halocline. ${ }^{1}$

1. While tracer studies clearly show shelf ventilation of the halocline (e.g., cf., Moore and Smith, 1986; Wallace, Moore and Jones, 1987), the primary mechanism for maintenance of this principal density structure in the Arctic Ocean has been debated in the literature (cf., Aagaard, Coachman and Carmack, 1981; Rudels, Anderson and Jones, 1996; Steele and Boyd, 1998; and Woodgate, Aagaard, Muench, Gunn, Björk, Roach and Schauer, in press, for different emphases and views). 


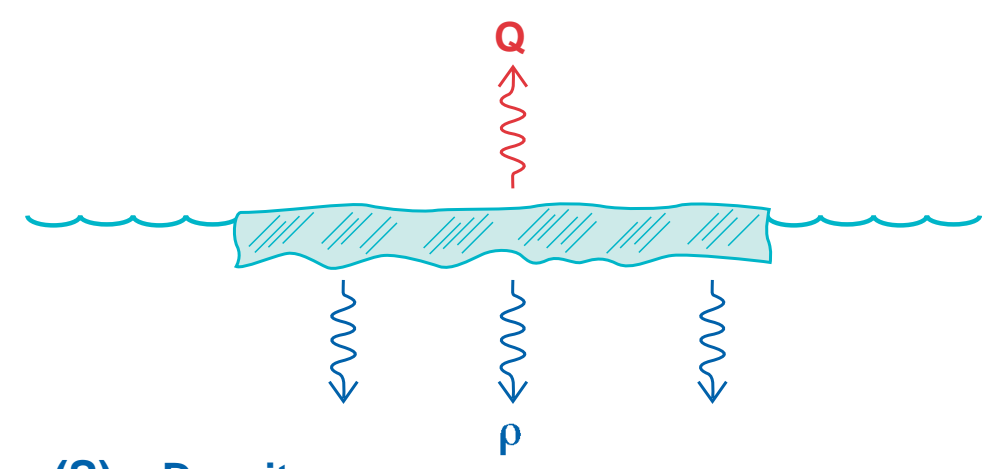

$\rho(\mathbf{S})=$ Density

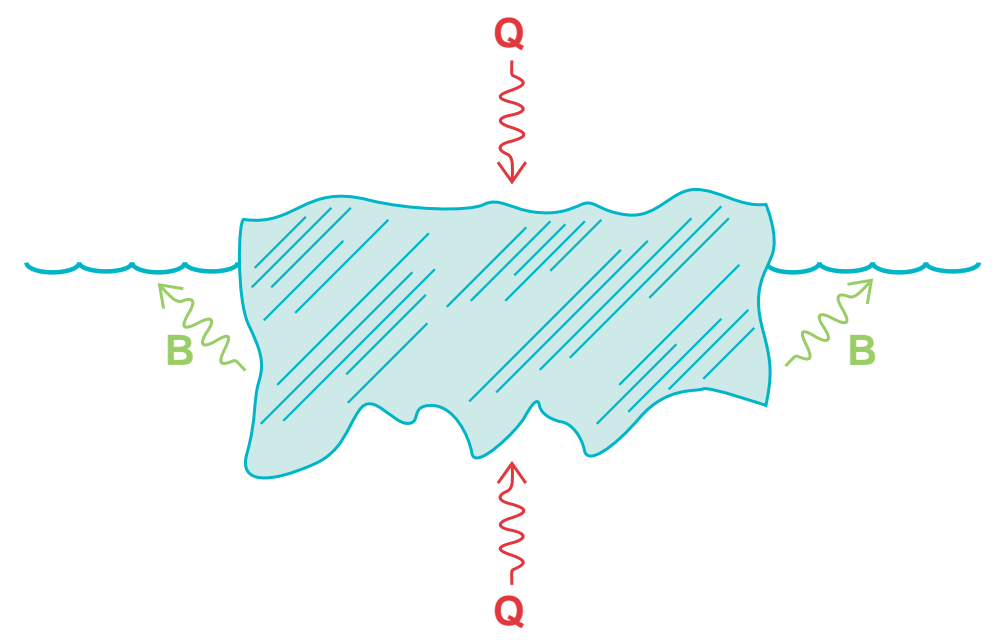

$\mathrm{B}(\mathrm{S})$ = Buoyancy

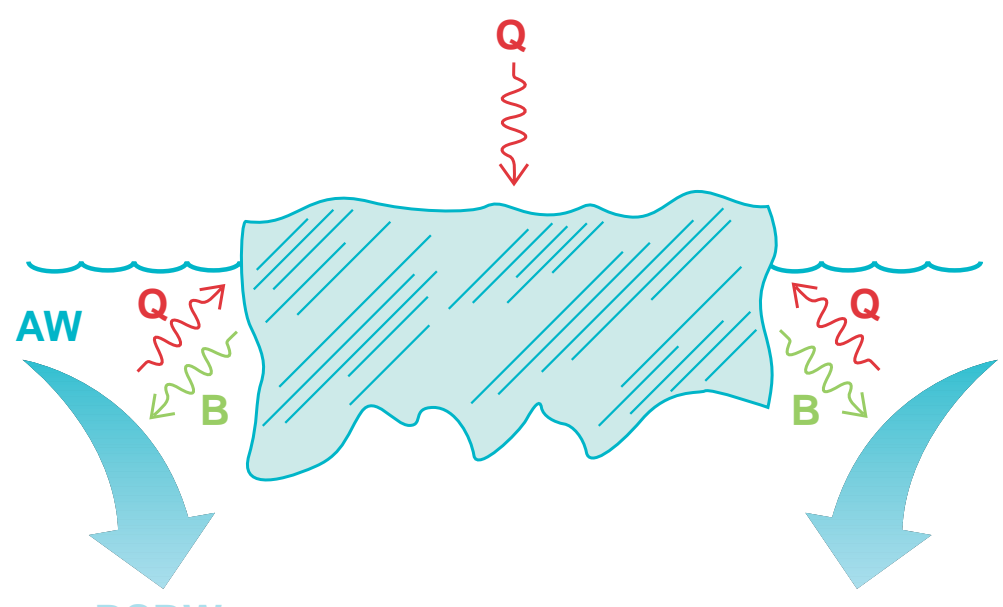

Residue injected

Process:

- Haline convection

Example:

- Halocline maintenance

\section{Distillate caps ocean}

Process:

- Suppression of convection

Example:

- Stratified upper Arctic Ocean

- Interruption of thermohaline circulation

\section{Distillate injected}

Process:

- Entrainment by independently maintained dense flow, or,

- Convection with thermobaric instability

Examples:

- Injection of BSBW to form an Arctic Ocean intermediate water - Low-salinity Greenland Sea deep water

Figure 2. Schematic representation of the disposition in the high-latitude ocean of distillation products resulting from freezing of seawater and subsequent melting. Heat fluxes are denoted by $\mathbf{Q}$ and buoyancy fluxes by $\mathbf{B}$. 
In the second case the distillate (in the form of low-salinity meltwater) caps the ocean and suppresses convection. The present stratified Arctic Ocean is likely in part a result of this process (Aagaard, Coachman and Carmack, 1981; Rudels, Anderson and Jones, 1996). In the extreme case, it has been hypothesized that the global overturning cell in the ocean might be disrupted by such capping in open-ocean regions that would otherwise convect during winter (Aagaard and Carmack, 1989; Häkkinen, 1993; Delworth, Manabe and Stouffer, 1997).

In the third case the meltwater is injected into the interior ocean, possibly aided by the enhanced compressibility of cold water, which permits thermobaric instability to develop (cf., Gill, 1973 for an early discussion). The maintenance of the low-salinity Greenland Sea deep water has been suggested to be an example of the latter influence, since the low-salinity surface waters that ventilate the deep Greenland Sea are very cold and their sinking may therefore be aided by the thermobaric effect (Aagaard and Carmack, 1989). The present calculations suggest that the entry of the BSBW into the intermediate-depth Arctic Ocean is another example of the injection of ice melt into the interior ocean, but in this case without a thermobaric boost, since the injected water is warmer than the ambient ocean. We note that the injection of BSBW instead results from the cooling of waters transiting the shelf as part of a large-scale circulation. The cooling of the throughflow allows the meltwater (together with precipitation and runoff) to be injected without reducing the initial density of the throughflow water, since the opposing effects on density of cooling and freshening on the shelf nearly balance. In summary, ice is exported southward from the Arctic Ocean onto the Barents shelf, melts, and is then entrained into the northward Barents Sea throughflow that subsequently sinks within the Arctic Ocean. A curious feature of this process is that water distilled at the surface of the Arctic Ocean by freezing ends up at mid-depth in the same ocean!

As ice conditions in the Arctic Ocean and adjacent seas vary, now or in the future, these ice-ocean interactions will likely also change. For example, if brine injection is a controlling process, less ice on the shelves in summer (and therefore more open water at the start of freezing in fall) would likely result in more freezing each winter, increased brine injection, and therefore a better ventilated interior Arctic Ocean (Melling, 1993; Aagaard and Carmack, 1994). Similarly, if meltwater capping exerts primary control on vertical exchange in the Greenland Sea, less sea ice there would probably lead to less meltwater capping, thereby reducing upper ocean stratification, which in turn would lead to intensification of the thermohaline overturning circulation (Delworth, Manabe and Stouffer, 1997).

On the other hand, if meltwater injection is a controlling process in determining the density structure of the interior ocean, then the effects of less ice will in part depend on the extent to which thermobaric instability is important. For example, if less ice in the Greenland Sea resulted in the cold upper layer in winter showing little salinity stratification, then the temperature contrast between the surface layer and the underlying water would be small. This would largely eliminate thermobaric effects (which aid the sinking of cold water), resulting in warmer, saltier, and less dense deep water than at present. In contrast, in the case of the Barents shelf, the saltier water on the shelf resulting from less meltwater would be denser than at present and would sink deeper into the Arctic Ocean. With respect to the BSBW, were the current approximately one-third ice-melt effect removed, but things otherwise not changed, the potential temperature of transformed Atlantic water would be $0^{\circ} \mathrm{C}$ and the salinity 34.95 . The density of that water would then be close to $0.06 \mathrm{~kg} \mathrm{~m}^{-3}$ greater than it is now (referenced to surface pressure), and the slightly more saline core of the new BSBW would lie about $500 \mathrm{~m}$ deeper in the Arctic 
Ocean than is presently the case (1300 m vs. $800 \mathrm{~m}$ over the Laptev Sea slope). We would therefore see a warmer and saltier Arctic Ocean between 800-1300 m. Would that, for example, in turn lead to a warmer deep Greenland Sea, since the latter is fed at depth from the Arctic Ocean (Aagaard, Fahrbach, Meincke and Swift, 1991)? In this connection, recall that the ice-melt portion of the total heat loss from the Atlantic water in its transformation on the shelf is only about $4 \%$, so that a significantly changed interior density structure in the Arctic Ocean need not be associated with large changes in the surface heat budget.

Finally, we suggest that a prototype of such BSBW variability may already exist, since varying conditions in the Barents Sea with respect to both the properties of the inflowing Atlantic water and the rate of southward flow of ice onto the shelf from the Arctic Ocean, will over a few years lead to a spectrum of BSBW versions being formed (cf., Woodgate, Aagaard, Muench, Gunn, Björk, Roach and Schauer, in press, for an example), perhaps sufficient to illustrate what is possible under reasonable variations in future climatic forcing. If so, the recent stream of observations pouring out of the Eurasian Basin may point to the possible further evolution of the interior Arctic Ocean.

Acknowledgment: We appreciate the helpful comments of the two anonymous reviewers. We especially thank the reviewer who suggested an early version of Figure 1 . The Office of Naval Research, grant N00014-99-1-0321 provided partial financial support. 


\section{References}

Aagaard, K., L.K. Coachman and E.C. Carmack (1981) On the halocline of the Arctic Ocean. Deep-Sea Research, 28, pp. 529-545.

Aagaard, K., E. Fahrbach, J. Meincke and J.H. Swift (1991) Saline outflow from the Arctic Ocean: Its contribution to the deep waters of the Greenland, Norwegian, and Iceland seas. Journal of Geophysical Research, 96, pp. 20,433-20,441.

Aagaard, K. and E.C. Carmack (1989) The role of sea ice and other fresh water in the arctic circulation. Journal of Geophysical Research, 94, pp. 14,485-14,498.

Aagaard, K. and E.C. Carmack (1994) The Arctic Ocean and climate: A perspective. In: The Polar Oceans and Their Role in Shaping the Global Environment, Geophysical Monographs, 85, O.M. Johannessen, R.D. Muench and J.E. Overland, editors, American Geophysical Union, pp. 5-20.

Barry, R.G. and M.C. Serreze (2000) Atmospheric components of the Arctic Ocean freshwater balance and their interannual variability. In: The Freshwater Budget of the Arctic Ocean, NATO Science Series 2, Vol. 70, E.L. Lewis, editor, Kluwer, pp. 45-56.

Blindheim, J. (1989) Cascading of Barents Sea bottom water into the Norwegian Sea. Rapports Proces-verbaux Reunion Conseil International Exploration de la Mer, 188, pp. 49-58.

Blindheim, J. and H. Loeng (1981) On the variability of Atlantic influence in the Norwegian and Barents seas. Fiskeridirektoratets Skrifter Serie Havundersøkelser, 17, pp. 161-189.

Cooper, L.W., T. Beasley, K. Aagaard, J.M. Kelley, I.L. Larsen and J.M. Grebmeier (1999) Distributions of nuclear fuel-reprocessing tracers in the Arctic Ocean: Indications of Russian river influence. Journal of Marine Research, 57, pp. 715-738.

Delworth, T.L., S. Manabe and R.J. Stouffer (1997) Multidecadal climate variability in the Greenland Sea and surrounding regions: a coupled simulation. Geophysical Research Letters, 24, pp. 257-260.

Ekwurzel, B. (1998) Circulation and mean residence times in the Arctic Ocean derived from tritium, helium, and oxygen-18 tracers, Ph.D. thesis, Columbia Univ., New York.

Ekwurzel, B., P. Schlosser, J.H. Swift, R.A. Mortlock and R.G. Fairbanks (submitted) River runoff, sea ice meltwater, and Pacific water distribution and mean residence times in the Arctic Ocean. Journal of Geophysical Research.

Foldvik, A., T. Gammelsrød and T. Tørresen (1985) Physical oceanography studies in the Weddell Sea during the Norwegian Antarctic Research Expedition 1978/79, Polar Research, 3, 195-207.

Frank, M. (1996) Spurenstoffuntersuchungen zur zirkulation im Eurasischen Becken des Nordpolarmeeres, Ph.D. thesis, Ruprecht Karls Universität Heidelberg.

Gill, A.E. (1973) Circulation and bottom water production in the Weddell Sea. Deep-Sea Research, 20, pp. 111-140.

Guay, C.K. and K.K. Falkner (1997) Barium as a tracer of Arctic halocline and river waters. Deep-Sea Research, Part II, 44, pp. 1543-1569.

Häkkinen, S. (1993) An arctic source for The Great Salinity Anomaly: A simulation of the arctic ice-ocean system for 1955-1975. Journal of Geophysical Research, 98, pp. 16397-16410.

Holland, D.M., L.A. Mysak and J.M. Oberhuber (1996) Simulation of the mixed-layer circulation in the Arctic Ocean. Journal of Geophysical Research, 101, pp. 1111-1128.

IAEA/WMO (1999) Global Network for Isotopes in Precipitation. The GNIP Database.

Release 3, October 1999. URL: http://www.iaea.org/programs/ri/gnip/gnipmain.htm. 
Kershaw, P. and A. Baxter (1995) The transfer of reprocessing wastes from northwest Europe to the Arctic. Deep-Sea Research, Part II, 42, pp. 1413-1448.

Loeng, H., V. Ozhigin, B. Ådlandsvik and H. Sagen (1993) Current measurements in the northeastern Barents Sea. In: Proceedings, ICES Statutory Meeting 1993, International Council for the Exploration of the Sea, ms. C.M. 1993/C:41.

Macdonald, R.W., D.W. Paton and E.C. Carmack (1995) The freshwater budget and under-ice spreading of Mackenzie River water in the Canadian Beaufort Sea based on salinity and ${ }^{18} \mathrm{O} /{ }^{16} \mathrm{O}$ measurements in water and ice. Journal of Geophysical Research 100, pp. 895-919.

Melling, H. (1993) The formation of a haline shelf front in wintertime in an ice-covered arctic sea. Continental Shelf Research, 13, pp. 1123-1147.

Mensch, M., M. Frank, W. Stein and R. Bayer (submitted) Water mass distribution and circulation in the Eurasian Basin of the Arctic Ocean. Journal of Geophysical Research.

Moore, R.M., and J.N. Smith (1986) Disequilibria between ${ }^{226} \mathrm{Ra},{ }^{210} \mathrm{~Pb}$ and ${ }^{210} \mathrm{Po}$ in the Arctic Ocean and the implications for chemical modification of the Pacific water inflow, Earth and Planetary Science Letters, 77, pp. 285-292.

Mosby, H. (1970) Atlantic water in the Norwegian Sea. Geofysiske Publikasjoner, 28, pp. $1-60$.

Olsson, K. and L.G. Anderson (1997) Input and biogeochemical transformation of dissolved carbon in the Siberian shelf seas. Continental Shelf Research, 17, pp. 819833.

Östlund, H.G. and G. Hut (1984) Arctic Ocean water mass balance from isotope data. Journal of Geophysical Research, 89, pp. 6373-6381.

Rudels, B., L.G. Anderson and E.P. Jones (1996) Formation and evolution of the surface mixed layer and halocline of the Arctic Ocean. Journal of Geophysical Research, 101, pp. 8807-8821.

Rudels, B., E.P. Jones, L.G. Anderson and G. Kattner (1994) On the intermediate depth waters of the Arctic Ocean. In: The Polar Oceans and Their Role in Shaping the Global Environment, Geophysical Monographs, 85, O.M. Johannessen, R.D. Muench and J.E. Overland, editors, American Geophysical Union, pp. 33-46.

Schauer, U., R.D. Muench, B. Rudels and L. Timokhov (1997) Impact of eastern Arctic shelf waters on the Nansen Basin intermediate layers. Journal of Geophysical Research, 102, pp. 3371-3382.

Schlosser, P., D. Grabitz, R. Fairbanks and G. Bönisch (1994) Arctic river-runoff: Mean residence time on the shelves and in the halocline. Deep-Sea Research, 41, pp. 1053-1068.

Steele, M. and T. Boyd (1998) Retreat of the cold halocline layer in the Arctic Ocean, Journal of Geophysical Research, 103, pp. 10,419-10,435.

Steele, M. and G.M. Flato, (2000) Sea ice growth, melt, and modeling: A survey. In: The Freshwater Budget of the Arctic Ocean, NATO Science Series 2, Vol. 70, E.L. Lewis, editor, Kluwer, pp. 549-587.

Steele, M. and J.H. Morison (1993) Hydrography and vertical fluxes of heat and salt northeast of Svalbard in autumn. Journal of Geophysical Research, 98, pp. 10,01310,024 .

Vinje, T., N. Nordlund and Å. Kvambekk (1998) Monitoring ice thickness in Fram Strait. Journal of Geophysical Research, 103, pp. 10,437-10,450.

Wallace, D.W., R.M. Moore, and E.P. Jones (1987) Ventilation of the Arctic Ocean cold halocline: Rates of diapycnal and isopycnal transport, oxygen utilization, and primary 
production inferred using chlorofluoromethane distribution, Deep-Sea Research, 34, pp. 1957-1980.

Woodgate, R.A., K. Aagaard, R.D. Muench, J. Gunn, G. Björk, A.T. Roach and U. Schauer (in press) The Arctic Ocean boundary current along the Eurasian slope and the adjacent Lomonosov Ridge: Water mass properties, transports and transformations from moored instruments. Deep-Sea Research. 


\section{List of figures.}

Figure 1. Contours of the fractional freshening of the Atlantic water on the Barents shelf due to ice melt, for a range of salinity (ordinate) and $\Delta^{18} \mathrm{O}$ (abscissa) associated with the various mixing components. The stars represent the freshening corresponding to the parameter choices of Table 1.

Figure 2. Schematic representation of the disposition in the high-latitude ocean of distillation products resulting from freezing of seawater and subsequent melting. Heat fluxes are denoted by $\mathbf{Q}$ and buoyancy fluxes by $\mathbf{B}$. 